\title{
DEVELOPMENT OF A DISC TRIBOMETER AND DETERMINATION OF ITS OPTIMAL PARAMETERS AND MODES OF CONTACT INTERACTION OF COMPOSITES WITH RAW COTTON
}

\author{
Tukhtasheva M.T. ${ }^{1}$, Eshkobilov O.Kh. ${ }^{2}$ \\ ${ }^{1}$ Tashkent Institute of Chemical Technology, Uzbekistan \\ ${ }^{2}$ Karshi Engineering and Economic Institute, Uzbekistan \\ E-mail: red_engineer94@mail.ru
}

\begin{abstract}
A disk tribometer has been developed to determine the tribotechnical properties of composites working in interaction with raw cotton. The results of a comprehensive analysis of studies of the optimal parameters of a disk tribometer and modes of contact interaction of machinebuilding composite polymer materials with raw cotton are presented. The influence of moisture and contamination of raw cotton, sliding speed and specific pressure on the antifriction properties of antifriction-wear-resistant epoxy compositions were investigated.
\end{abstract}

Keywords: Disk tribometer, Cylindrical box, Parameter, Coefficient of friction, Temperature in the friction zone, Density of triboelectric charge, Epoxy composition, Contamination, Moisture, Raw cotton.

\section{Introduction}

It is known that when harvesting and processing raw cotton, special attention is paid to obtaining highquality cotton fiber and achieving the maximum yield of the latter by reducing losses during harvesting, transportation, and processing of cotton [1].

One of the main tasks aimed at preserving the natural properties of cotton fiber is to reduce the mechanical damage to raw cotton when it interacts with the working bodies of machines and mechanisms. To solve it, some constructive technological measures are carried out, consisting in optimizing the parameters of the working bodies of machines and reducing the roughness of their surface, as well as in increasing the operational properties of structural materials from which parts of the working bodies of machines are made [1].

It is known that one of the most important performance characteristics of the material for the working bodies of machines, which ensures the maximum preservation of the natural properties of cotton, is its antifriction property [1]. It should be noted that at present there is no unified methodology for studying the anti-friction characteristics of structural materials in their interaction with cotton.

In this regard, the development of a method and installation for studying the antifriction properties of machine-building composite polymer materials (CPM) interacting with raw cotton is an urgent task.
One of the possible ways to solve this problem is the introduction of new composite metal-polymer materials and coatings based on them with predetermined anti-friction-wear-resistant antistatic-heat conductive properties in the parts of rubbing pairs of working bodies of machines and mechanisms intended for transportation, dismantling riots, digging tunnels, etc. processing of raw cotton, operated in ginneries and having identical scooping elements in the form of pegs made of steel and expensive non-ferrous metals.

This will improve the quality of cotton fibers and seeds by preserving their natural properties during their transportation and processing of raw cotton, but will also provide a significant increase in the reliability and durability of working parts by reducing the friction forces of the polymer-cotton pair. At the same time, the mechanical damageability of raw cotton is significantly reduced both due to a decrease in the roughness of the surfaces of the working organs and due to the high elasticity and damping properties of polymeric materials. It will also save material and labor costs by eliminating some technological operations for the machining of the surfaces of parts of rubbing pairs of working bodies of machines and mechanisms [1].

Disc tribometer. The friction of structural materials interacting with raw cotton is distinguished by the variety and complexity of the processes occurring simultaneously. Therefore, many researchers $[1,3]$ have modeled friction with raw cotton in various installations. Based on this, we 
have developed a disk tribometer installation and a method for determining antifriction properties friction force, temperature, and the magnitude of the electrostatic charge of machine-building composite antistatic heat-conducting polymeric materials when interacting with raw cotton, operating in the pressure range from 0.001 to $0.05 \mathrm{MPa}$ and speeds from 0.5 to $10 \mathrm{~m} / \mathrm{c}$ [1-2].

The essence of the method is that the friction of the fibrous material is carried out on the flat surface of a rotating disk sample made of the material under study at some preset values of the clamping pressure $\mathrm{P}$ and sliding velocity $\mathrm{V}$, the values of the friction forces, temperatures, and values of the electrostatic charges of the test sample are measured in the friction zone with cotton. raw, after processing the measurement results, it is possible to judge the range of permissible values of $\mathrm{P}, \mathrm{V}$ and determine the working conditions of the test material.

A schematic diagram of a disk tribometer for determining the friction force between a structural composite material and raw cotton, the temperature, and the magnitude of the static electricity charge in the friction zone is shown in Fig. 1.

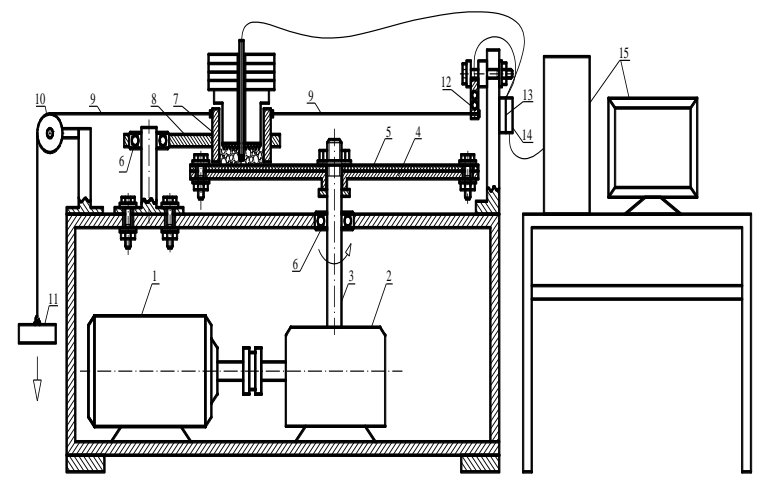

Figure 1: Schematic diagram of a disk tribometer.

1 - electric motor; 2 -reducer; 3-vertical shaft, 4 - disc; 5 - polymer-coated or composite sample; 6 - ball bearing; 7 piston; 8-cylindrical box,9 - cable, 10 - block; 11-bowl for

loading, 12- measuring bar, 13- ASP converter, 14microcontroller, 15-computer

The disk tribometer works as follows: From the electric motor 1 and the gearbox 2, a vertical shaft 3 is set in motion with a horizontal disk 4 mounted on it. A sample 5 of the material under test is placed on the disk. To prevent axial and radial runout, the disc shaft is mounted on two radial and one thrust bearing 6 . The piston 7 is inserted into a cylindrical box 8 with packed raw cotton, located on eight deep groove ball bearings 6 , moves in the longitudinal direction. The use of deep groove ball bearings reduces the friction force between the sidewalls of the box and the guide frame. The guide frame can be moved vertically if required. the inner side of the wall has four vertical channels filled with balls. Cables 9 are attached to the box on both sides.
One of them is thrown over block 10 to cup 11 and serves for tared rewarding. Another cable is also connected to the box, and its other end is connected to a measuring beam, on which are glued HX711 12 strain gauges with software for determining the friction force on rubbing pairs "composite - fibrous mass" [4].

This software product [4] is intended to determine the friction force on rubbing pairs "solidfibrous mass" using the HX711 strain gauge; converting information from the strain gauge with a display on the monitor to assess the antifriction properties of contacting surfaces through graphic and numerical values, subsequently establishing and selection of the optimal solid surface.

The program includes entering the values of the load to the contacting surface, sliding speed in contact, obtaining information about the friction force from the strain gauge, and transferring the obtained data with a graphical display on the monitor and through the numerical values of the friction force in the contact of the rubbing pair.

The functionality of the proposed software product consists of the implementation of the tasks of choosing a material with an optimal friction surface of a counter body with a fibrous mass that does not damage the fibers while maintaining their natural properties. The implementation of the specified functionality is carried out based on algorithms for optimal, reliable, and individual control with unknown parameters in the friction zone.

The program can be used when choosing a material or coating on steel products with a minimum value of the friction force in contact.

The disk tribometer complex for amplification of metric signals received from strain gauges and their recording includes 13 - ASP converter, 14 microcontroller, and 15 - computer.

A sample of the investigated material [5] is made following Fig. 2.

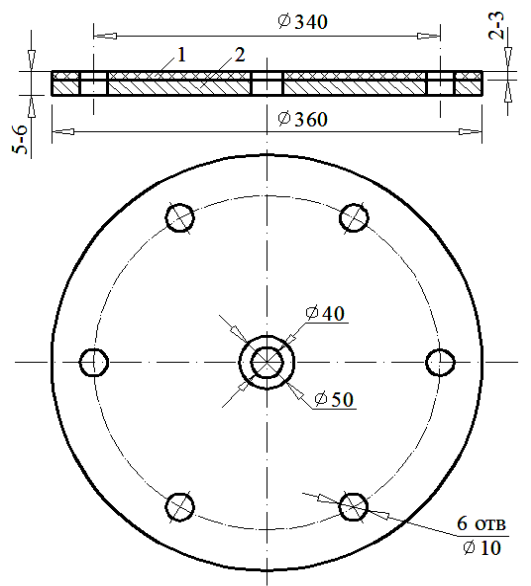

Figure 2: Sample of the test material. 1-steel disc; 2 - test coating or composite material 
Method for determining the coefficient of friction of composite antistatic-heat-conducting polymeric materials when interacting with raw cotton [7-10]. Raw cotton is laid inside the cylindrical box, and a piston with weights is placed on top. When the disk rotates, the sample - a composite polymer material carries along with a cylindrical box with a sample of raw cotton and thereby pulls the cable, which, in turn, bends the beam with strain gauges. The mechanical deformation of the beam is converted into electrical vibrations using strain gauges and the signals are recorded on the monitor screen.

After finding the friction force, the coefficient of friction between the composite polymer material and the raw cotton was calculated using the wellknown formula

$$
\mathrm{f}=\Sigma \mathrm{f}_{\mathrm{i}} / \mathrm{n},
$$

where $f_{i}=F / N ; F-$ friction force, $N$;

$\mathrm{N}$ - normal force acting on rubbing pairs, $\mathrm{N}$;

$\mathrm{n}$ - number of experiments performed.

The measurement accuracy of the disk tribometer is $0.5-1.5 \%$. The limit of permissible error in measuring the friction force of the contacting surfaces, the temperature arising in the friction zone, and the magnitude of the electrostatic charge from the measured value in the entire range of sliding speeds and generated pressures is \pm 5.0 .

The gap between the test piece and the box should be no more than $1 \mathrm{~mm}$.

\section{Research Objects and Methods}

Antifriction-wear-resistant composite polymer coatings based on ED-16 epoxy resin and mediumfiber raw cotton of the C-6524 variety of the 1st grade of manual and machine harvesting were selected as objects of research. The friction coefficient, the temperature in the friction zone, and the density of the triboelectric charge of antifrictionwear-resistant composite polymer coatings based on ED-16 epoxy resin were determined using O'z DST 3330: 2018 [11].

The main parameters of the disk tribometer are the distance from the center of the disk to the center of the cylindrical box, which in what follows we will call the friction radius $\mathrm{R}_{\mathrm{fr}}$, the diameter of the cylindrical box $d_{r}$ and the height of the cylindrical box $h_{k}$ [12]. The friction radius $R_{f r}$, the diameter of the cylindrical box $d_{r}$, and the height of the cylindrical box $h_{k}$ can significantly affect the readings of the instruments when measuring the antifriction properties of the polymer and composite polymer materials when rubbed with raw cotton.

In this regard, studies of the influence of the main parameters of a disk tribometer on the coefficient of friction of epoxy composites when interacting with raw cotton play an important practical role in the selection of polymers and the development of composite materials for parts of the working bodies of various machine-building machines and mechanisms.

\section{Results and Discussion}

The influence of the main parameters (friction radius, duct diameter, duct height) of a disk tribometer on the friction coefficient of epoxy composite materials when interacting with raw cotton has been investigated.

The results of our experimental studies (Fig. 3) showed that with an increase in the friction radius $\mathrm{R}_{\mathrm{fr}}$, at any sliding speeds, the friction coefficient of epoxy compositions with raw cotton first decreases intensively, then basically stabilizes.

This is explained by the fact that at small values of the friction radius, the effect of the difference in the linear sliding velocities of the elementary friction contact areas along the friction radius will increase, as a result of which there is strong disorientation of the fibers in the contact zone, leading to an increase in the actual contact area (FPC) [12-13] and therefore, the force of frictional interaction increases. And the stabilization of the friction coefficient $\mathrm{f}$ with a friction radius equal to $\mathrm{R}_{\mathrm{fr}}=140$ $160 \mathrm{~mm}$ is explained by a decrease in the difference in linear velocities, which promotes the orientation of cotton fibers, which leads to a decrease in the FPC, and, accordingly, to a decrease in the density of the triboelectric charge and the temperature in the friction zone (Fig. 3). Such a nature of the change in the coefficient of friction, charge, and temperature is explained by the fact that at high values of $\mathrm{R}_{\mathrm{fr}}$, the temperature value decreases as a result of its transfer to the environment through the large disk surface, and at lower values, the contact frequency increases, as a result of which the formation of a triboelectric charge is intensified. and temperatures in the friction zone, which, in turn, increase the molecular component of the friction coefficient due to an increase in FPC with cotton due to the deterioration of the physical and mechanical properties of the surface layer of polymeric materials. 


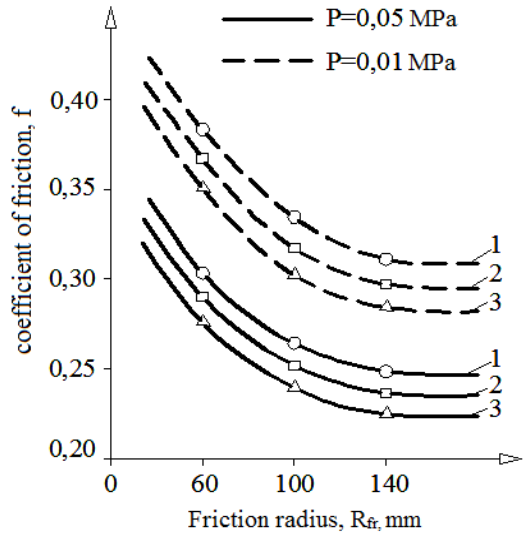

a)

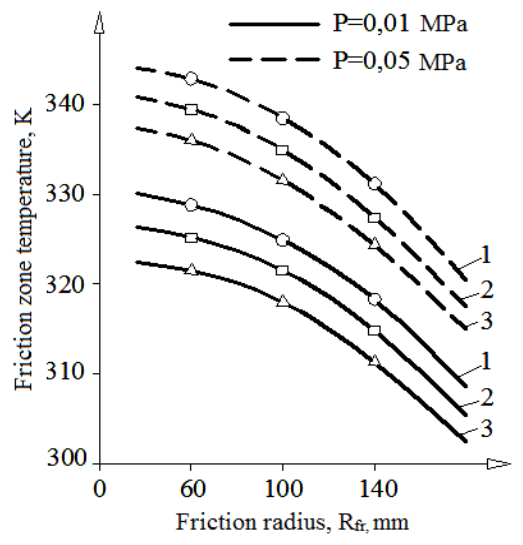

b)

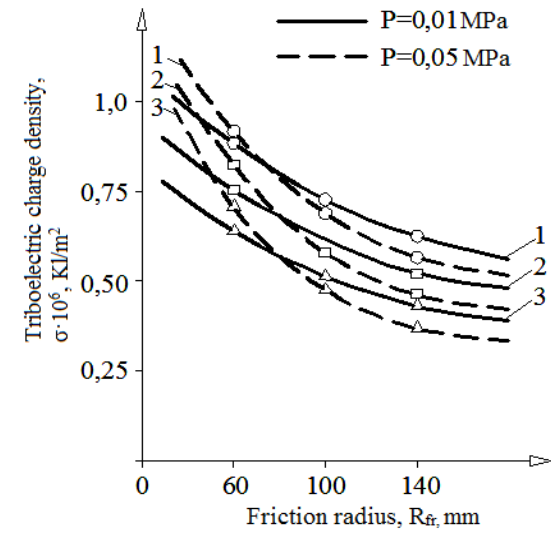

c)

Figure 3: Dependence of the friction coefficient (a), the temperature in the friction zone (b), and the density of the triboelectric charge (c) on the friction radius during the interaction of the epoxy composite with raw cotton. 1 - $V=6$ $\mathrm{m} / \mathrm{c} ; 2-\mathrm{V}=4 \mathrm{~m} / \mathrm{c} ; 3-\mathrm{V}=1 \mathrm{~m} / \mathrm{c}$

It should be noted that the greater the pressure and sliding speed, the stronger the influence of the friction radius $R_{f r}$ on the value of the friction coefficient $f$ and the density of the triboelectric charge in the zone of interaction of polymer materials with raw cotton.

The data obtained show that the optimal friction radius lies within $140 \div 160 \mathrm{~mm}$, namely, in the region of transition to stable indications of its properties.

The second parameter of the disk tribometer, which determines the actual contact area (FPC) between the pulp and the polymer material and, accordingly, the antifriction properties of the latter, is the diameter of the cylindrical box $\mathrm{d}_{\mathrm{r}}$.
Studies have shown (Fig. 4) that with an increase in the diameter of a cylindrical box to $80 \mathrm{~mm}$ and more, an increase in the coefficient of friction of epoxy compositions interacting with raw cotton is observed. And when the box diameter $\mathrm{d}_{\mathrm{k}}$ is less than $80 \mathrm{~mm}$, apparently, under the influence, the stiffness of the raw cotton mass increases, and the surface contact becomes more discrete, which leads to a decrease in the FPC and a slight decrease in the friction coefficient. An increase in the diameter of the cylindrical duct increases the coefficient of mutual overlap, which leads to an increase in FPC, accumulation of triboelectric charge, and an increase in temperature in the friction zone, and, consequently, in the coefficient of friction.

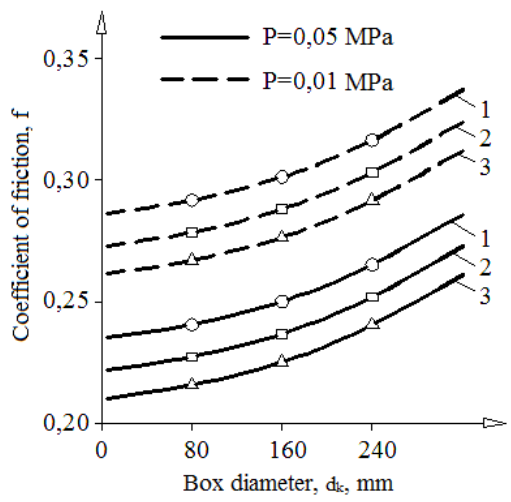

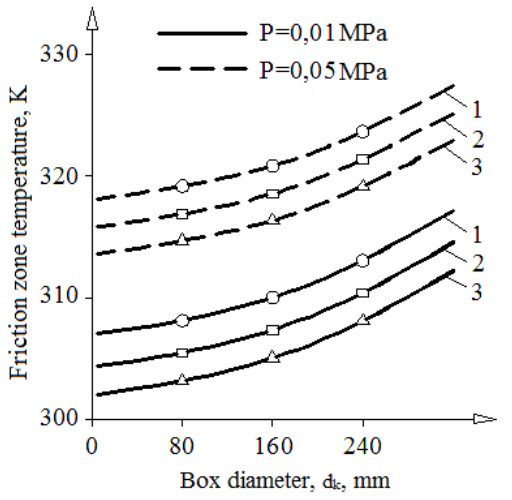

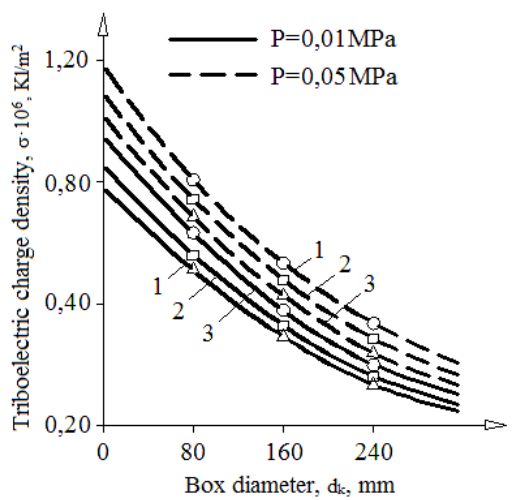

c)

Figure 4: Dependence of the friction coefficient (a), the temperature in the friction zone (b), and the value of the density of the triboelectric charge (c) on the duct diameter when the epoxy composite interacts with raw cotton. 1 $V=6 \mathrm{~m} / \mathrm{c} ; 2-V=4 \mathrm{~m} / \mathrm{c} ; 3-V=1 \mathrm{~m} / \mathrm{c}$

Thus, the optimal diameter of the cylindrical box $\mathrm{dk}$ should be considered its value in the range of $80 \div$ $100 \mathrm{~mm}$, namely, in the transition region of the change in the antifriction properties of polymeric materials.

Since the interaction of raw cotton with the polymer has its peculiarities, namely, taking into account its bulk density, which, in turn, depends on the parameter of the cylindrical box $d_{k}$ and pressure, it is obvious that the height of the cylindrical box $h_{k}$ is also one of the main parameters disk tribometer.

The dependence of the friction coefficient, triboelectric charge, and temperature in the zone of interaction of polymer materials with raw cotton on the height of the cylindrical box $h_{k}$ is shown in Fig. 5 . 
Fig. 5, it can be seen that the friction coefficient $\mathrm{f}$ with an increase in the height of the cylindrical box $h_{k}$ to values of $90 \mathrm{~mm}$ (Fig. 5, a) does not change, and with a further increase in $h_{k}$, its decrease is observed. This nature of the change in the coefficient of friction is explained by the fact that at $h_{\kappa} \leq 90 \mathrm{~mm}$ and a given load, the bulk density of raw cotton increases, and the coefficient of porosity decreases rapidly, as a result, the mutual mobility of individual elements of the mass of raw cotton is significantly reduced, which leads to an insignificant change in the coefficient of friction A decrease in the coefficient of friction with an increase in the height of the box is associated with an increase in the lateral pressure on the walls of the box, which leads to some decrease in the normal pressure transmitted through the cotton mass.

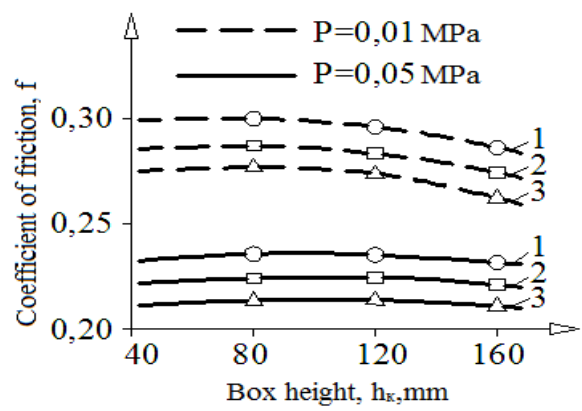

a)

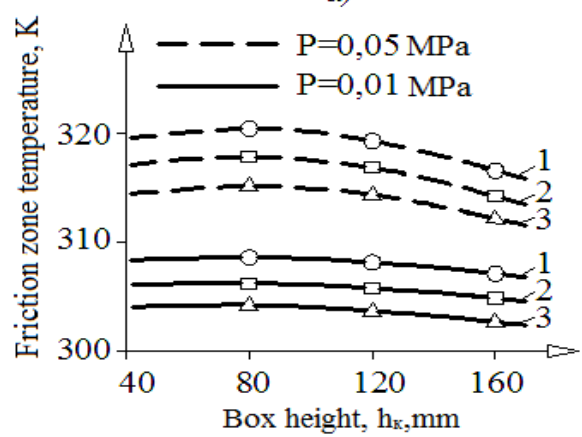

b)

Figure 5: Dependence of the coefficient of friction (a), temperature in the friction zone (b) on the height of the box when the epoxy composite interacts with raw cotton. 1 - at $V=6 \mathrm{~m} / \mathrm{c}$;

2- $a t V=4 \mathrm{~m} / \mathrm{c} ; 3-$ at $V=1 \mathrm{~m} / \mathrm{c}$

The results obtained show that the influence of the height of the cylindrical box $h_{k}$ on the coefficient of friction $f$ of polymer and composite polymer materials, according to the given data, is insignificant, but it must be considered as the optimal box height within $60 \div 80 \mathrm{~mm}$.

Dependence of the friction coefficient, temperature in the friction zone of epoxy composites on the contamination and moisture content of raw cotton, specific pressure, and sliding speed. Analysis of the operating conditions of the working bodies of machines and mechanisms intended for the transportation and processing of raw cotton shows that their working bodies, equipped with scoop elements made of steel, operate in conditions of high humidity and contamination of raw cotton. In this regard, the study of the effect of moisture and contamination of raw cotton on the antifriction properties of the polymer and composite polymer materials and coatings when rubbed with raw cotton is an urgent problem.

The working bodies of machines and mechanisms are in direct contact and are constantly in contact with raw cotton of varying moisture content, which has specific properties: tenacity, the dependence of characteristics on its moisture content, electrification during friction with polymers, relatively easy flammability, and scuffing properties. Therefore, when choosing polymer and composite polymer materials for the manufacture of peg working bodies, it is necessary to take into account the nature and patterns of their interaction with raw cotton.

Solving the important problem of creating antifriction-wear-resistant composite polymer materials and coatings based on a comprehensive study of the nature of the contact interaction of polymers with raw cotton will help to increase the working capacity and efficiency of machines and mechanisms for transporting and processing raw cotton.

Figure 6 shows the dependences of the friction coefficient of epoxy composites when interacting with raw cotton at various values of contamination and moisture, as well as at $\mathrm{V}=2 \mathrm{~m} / \mathrm{s}$ and $\mathrm{P}=0.01$ $0.05 \mathrm{MPa}$.
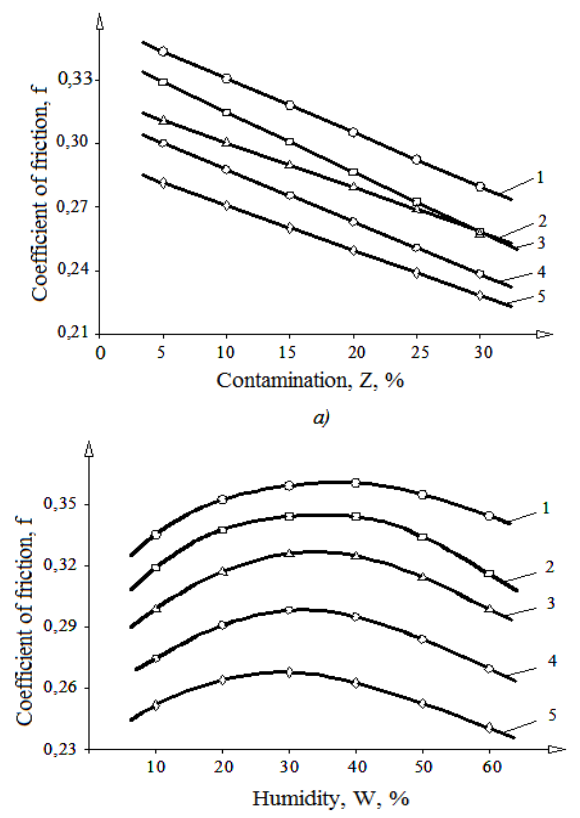

b)

Figure 6: Dependence of the coefficient of friction of epoxy composites when interacting with raw cotton of various contamination (a) and moisture (b) at $V=2 \mathrm{~m}$ /c. 1 - $P=0,01 \mathrm{MPa} ; 2-P=0,02 \mathrm{MPa} ; 3-P=0,03 \mathrm{MPa}$;4$P=0,04 \mathrm{MPa} ; 5-\mathrm{P}=0,05 \mathrm{MPa}$ 
As can be seen from Figure 6, with an increase in the moisture content of raw cotton, the friction coefficient increases to a certain value in this case by $25-30 \%$ and then decreases. The decrease in the coefficient of friction at high values of humidity is explained by the fact that physically adsorbed moisture affects the conditions for the formation of the actual contact area (ACA), conditions are created for free leakage of triboelectric charges formed during frictional interaction and the removal of temperature from the friction zone [14-15]. causes a change in the viscoelastic properties of raw cotton and, as a consequence, the actual contact area (ACA) with its polymer. In addition, an increase in moisture reduces the coefficient of friction due to the plasticizing and lubricating effect of moisture adsorbed on the surface of the cotton fibers.

Let us consider the effect of sliding speed and pressure on the quality indicators of raw cottons, such as contamination and moisture, as well as temperature on the coefficient of friction of polymeric materials at the optimal parameters of the tribometer, determined in the above studies.

The study of the influence of quality indicators of raw cotton on the antifriction properties of polymer coatings (Fig. 7) showed that these characteristics can significantly change the process of frictional interaction of polymer-cotton pairs.

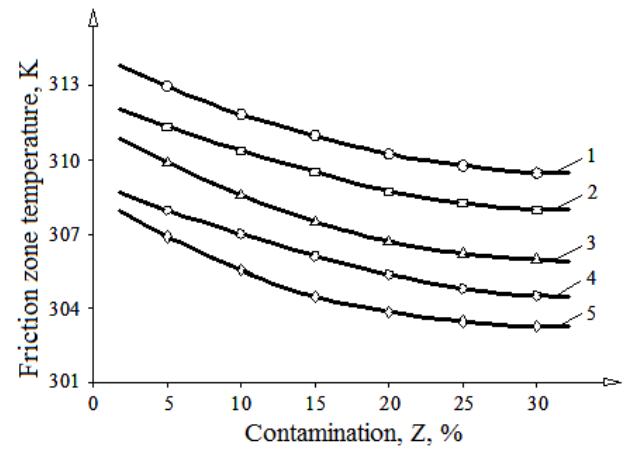

a)

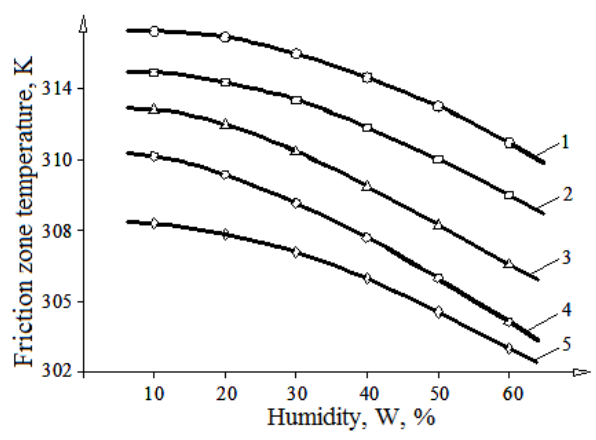

Figure 7: Dependence of temperature in the friction zone of epoxy composites during frictional interaction with raw cotton on contamination (a) and moisture

(b) at $V=2 \mathrm{~m} / \mathrm{c}$. 1-P=0,05 $\mathrm{MPa}$; $2-\mathrm{P}=0,04 \mathrm{MPa}$; 3$P=0,03 \mathrm{MPa} ; 4-\mathrm{P}=0,02 \mathrm{MPa} ; 5-\mathrm{P}=0,01 \mathrm{Mpa}$
An increase in the contamination of cotton leads to an increase in its elastic properties, rigidity, as a result of which the coefficient of friction of polymers with high mechanical properties decreases and increases for polymers with low mechanical properties.

Let us consider the results of studying the sliding friction coefficient of the investigated composite polymer coatings with raw cotton, depending on the sliding speed and specific pressure (Figs. 8 and 9).

Figures 8 and 9 show that the coefficient of friction of the epoxy composition with raw cotton has a complex dependence on the sliding speed and specific pressure. For most of the coatings under study, with an increase in the sliding speed up to 2-3 $\mathrm{m} / \mathrm{c}$, the sliding friction coefficient increases, and with a further increase in the speed, it decreases. This is explained by the fact that at low speeds, due to the viscoelastic properties of raw cotton and polymer coating, more bonds appear in the contact zone, the ACA, and, consequently, the coefficient of friction increase [15-16].

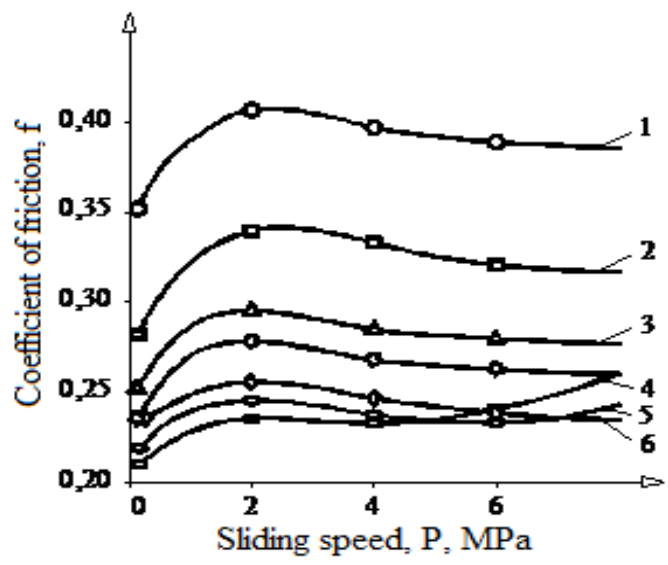

Figure 8: Dependence of the coefficient of friction of epoxy composition with raw cotton on the sliding speed at various specific pressures. 1 - 0,001; 2 - 0,005; 3 - 0,01; 4 - 0,02; 5 - 0,03; 6 - 0,04 $\mathrm{MPa}$

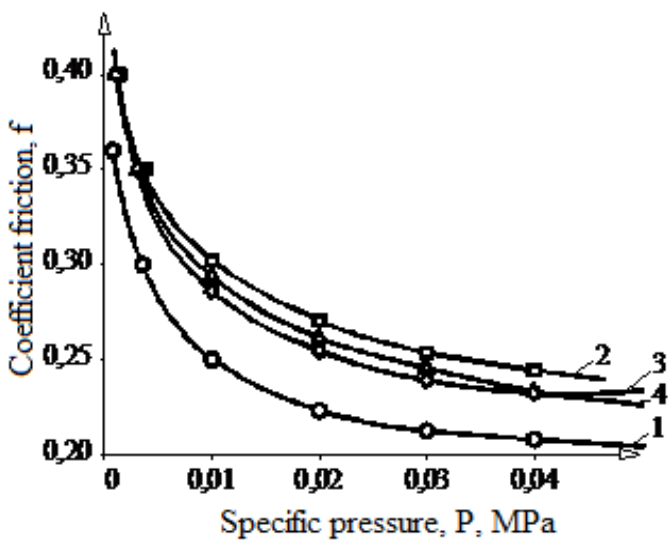

Figure 9: Dependence of the coefficient of friction of epoxy composition with raw cotton on specific pressure at different sliding speeds. $1-0,5 ; 2-2,0 ; 3-4,0 ; 4-6,0 \mathrm{~m} / \mathrm{c}$ 
A decrease in the coefficient of friction of the composition at a speed of 3-6 m / c and a specific pressure of $\mathrm{P}=0.02 \mathrm{MPa}$, as well as at a specific pressure of $\mathrm{P}=0.05 \mathrm{MPa}$ and a sliding speed $\mathrm{V}=2-3$ $\mathrm{m} / \mathrm{c}$, is associated with the predominance of bond failures over their formation in the contact zone [1620].

Figure 8 shows that with an increase in the specific pressure, the coefficient of friction of the epoxy composition with raw cotton first decreases intensively, then generally tends to stabilize. At high sliding speeds, this dependence for almost all compositions has an extreme character, passing through a minimum.

The research results show that with an increase in the sliding speed, the friction coefficient increases, which is explained by an increase in the number of bonds in the contact zone due to the viscoelastic properties of raw cotton and polymer material, as well as an increase in the density of the triboelectric charge and the temperature in the interaction zone, leading to a decrease in the elastic modulus and an increase in FPC, and, consequently, the coefficient of friction. With an increase in pressure, the coefficient of friction decreases, which can be explained by the compaction of the mass of raw cotton [21-23].

\section{Conclusions}

Thus, a disc tribometer has been developed to determine the tribotechnical properties of composites working in interaction with cotton-core. The influence of the main parameters (friction radius, diameter of a cylindrical box, height of a cylindrical box) of a disk tribometer on the coefficient of friction of an epoxy composite with raw cotton has been investigated. It was determined that with an increase in the nominal pressure on raw cotton, the friction coefficient of composite polymer materials generally decreases and the optimal values lie within the following limits: the average friction radius $\mathrm{R}_{\mathrm{fr}}=140-160 \mathrm{~mm}$, the diameter of the cylindrical box $70 \div 90 \mathrm{~mm}$ and the height of the box $60 \div 80 \mathrm{~mm}$. The regularities of the influence of moisture and contamination of raw cotton, sliding speed and specific pressure on the antifriction properties of antifriction-wear-resistant epoxy compositions have been established.

\section{References}

[1] Negmatov S.S.; Osnovy processov kontaktnogo vzaimodeistviya kompozicionnyh polimernih materialov s voloknistoy massoy [Fundamentals of the processes of contact interaction of composite polymer materials with fibrous mass], Tashkent, pub: Fan, 296p, 1984.
[2] Plastmassi.; Metod opredeleniya koefficienta treniya [Plastics. Method for determining the coefficient of friction], GOST 11629-2017. Standart inform, p8, 2018.

[3] Gulyamov G., Abed N.S., Negmatov S.S., Tuhtasheva M.N., Eshkabilov O. H.; Razrabotka i usovershenstvovanie ustroistva dlya izucheniya svoistv mashinostroitelnyh antifrikcionnoiznosostoikih antistaticheski-teploprovodyashih kompozicionnih polimernih, rabotayushih $\mathrm{V}$ usloviyah vzaimodeistviya s voloknistoy massoy [Development and improvement of a device for studying the properties of machine-building antifriction-wear-resistant antistatic-heatconducting composite polymer, operating under conditions of interaction with pulp], Kompozicionnie materiali, Volume 2, Pp: 117119, 2018.

[4] Eshkobilov O.H., Abdullaeva A.O.; Programma dlya EVM (baza dannih): Programmnoe obespechenie dlya opredeleniya sili treniya na trushihsya parah «tvyordoe telo - voloknistaya massa» s ispolzovaniem tenzodatchika HX711 [Computer program (database): Software for determining the friction force on rubbing pairs "solid - fibrous mass" using the HX711 strain gauge].- 2019.-12 s.

[5] Abed N.S., Negmatov S.S., Gulyamov G., Tuhtasheva M.N. Kompozicionnie antifrikcionnoiznosostoikie materiali i tehnologiya ih polucheniya [Composite anti-friction and wearresistant materials and technology for their production], Fan va texnologiya, 200p, 2017.

[6] Eshkobilov O. H., Rabbimov J. Sh.; Programma dlya EVM (baza dannih): Programmnoe obespechenie dlya opredeleniya temperaturi $\mathrm{V}$ zone treniya na trushihsya parah «tvyordoe telo voloknistaya massa» $\mathrm{s}$ ispolzovaniem tenzodatchika DS18B20 [Computer program (database): Software for determining the temperature in the friction zone on rubbing pairs "solid - fibrous mass" using the DS18B20 strain gauge], p12, 2020.

[7] Negmatov S.S., Gulyamov G., Abed N.S., Eshkabilov O.H.; Razrabotka metodologicheskogo sposoba opredeleniya koefficienta treniya antifrikcionno-iznosostoikih antistaticheski teploprovodyaschih kompozicionnyh polimernyh materialov i pokrytii na ih osnove $\mathrm{v}$ sisteme «kompozit-voloknistye materialy» [Development of a methodological method for determining the friction coefficient of anti-friction-wear-resistant antistatic-heat-conducting composite polymer materials and coatings based on them in the system "composite-fibrous materials"], Kompozicionnye materialy. Volume 1, p112, 2019.

[8] Negmatov S.S., Gulyamov G., Abed N.S., Eshkabilov O.H., Tuhtasheva M.N.; Metodika 
opredeleniya velichin elektrostaticheskih zaryadov i temperatur, voznikayuschih $\mathrm{v}$ zone treniya $\mathrm{v}$ tribosisteme «kompozit-voloknistye materialy» [Method for determining the values of electrostatic charges and temperatures arising in the friction zone in the tribosystem "compositefibrous materials"], Kompozicionnye materialy. Volume 1, Pp: 86-89, 2019.

[9] Eshkabilov O.H., Gulyamov G., Abed N.S., Negmatov S.S., Tuhtasheva M.N.; Ustanovka i metodika opredeleniya antifrikcionnih svoistv antistaticheski-teploprovodyaschih

kompozicionnih polimernih materialov, vzaimodeistvuyuschih s hlopkom-sircom [Installation and method for determining the antifriction properties of antistatic-heatconducting composite polymeric materials interacting with raw cotton], Uzbekskii jurnal Problemy mehaniki, Volume 2, Pp: 66-71, 2019.

[10] Gulyamov G., Abed N.S., Negmatov S.S.,Tuhtasheva M.N., Eshkabilov O. H.; Raschet deformacii i voznikayuschih napryajenii $\mathrm{v}$ izmeritelnoi balochke diskovogo tribometra dlya opredeleniya tribotehnicheskih harakteristik kompozicionnih polimernih materialov $\mathrm{s}$ voloknistoy massoy [Calculation of deformation and emerging stresses in the measuring beam of a disk tribometer to determine the tribotechnical characteristics of composite polymer materials with fibrous mass], Kompozicionnie materiali, Volume 2, Pp: 98-100, 2018.

[11] Negmatov S.S., Eshkabilov O.H., Abed N.S., Gulyamov G., Tuhtasheva M.N.; Metodi opredeleniya koefficienta treniya, temperaturi i velichini elektrostaticheskogo zaryada $\mathrm{v}$ zone treniya [Methods for determining the coefficient of friction, temperature and the magnitude of the electrostatic charge in the friction zone], $0^{\prime} z$ DSt 3330, p14, 2018.

[12] Eshkabilov O.H., Abed N.S., Gulyamov G., Negmatov S.S., Tuhtasheva M.N.; Issledovanie antifrikcionnih svoistv kompozicionnih polimernih materialov tribotehnichskogo naznacheniya, rabotayushih pri vzaimodeistvii s hlopkom-sircom [Investigation of antifriction properties of composite polymer materials for tribotechnical purposes, working in interaction with raw cotton], Uzbekskii himicheskii jurnal, Volume 2, Pp: 35-41, 2019.

[13] Saypidinov A., Umarov U.H., Djalalov T. et al.; Issledovanie formirovaniya FPK kompozicionnih polimernih materialov pri vzaimodeistvii $\mathrm{s}$ voloknistoy massoy [Investigation of the formation of FPC of composite polymer materials upon interaction with pulp], Kompozicionnie polimernie materiali i ih primenenie $\mathrm{v}$ narodnom hozyaistve: Tezisy dokladov $\mathrm{P}$ Vsesoyuznoi konferencii.Pp: 126-128, 1983.
[14] Kragelskiy I.V. Vinogradova I.E.; Koefficient treniya [Friction coefficient], Mashinostroenie, 228p 2013.

[15] Askadskiy A.A., Hohlov A.R.; Vvedenie v fizikohimiyu polimerov [Introduction to the physicochemistry of polymers], Nauchnyi mir, 384p, 2009.

[16] Installation and methodology for determining of antifrictional properties of antistatic heatconducting composite polymtric materials interacting with fibrous mass (cotton-raw), Technical science and innovation,Volume 2018, Issue 2, Pp: 20-23. Available at: https://uzjournals.edu.uz/btstu/ vol2018/iss2/1.

[17] Gulyamov G., Negmatov S.S., Tuhtasheva M.N., Abed N.S.; Konstrukcionnie materiali dlya detaley kolkovih rabochih organov mashin i mehanizmov, vzaimodeistvuyushih s hlopkomsyrcom [Structural materials for parts of peeling working bodies of machines and mechanisms interacting with raw cotton], Problemi tekstilya, Volume 3, Pp: 35-41, 2019.

[18] Gulyamov G. Antifrikcionnie i antifrikcionnoiznosostoikie polimernie kompozicionnie materiali na osnove poliolefinov [Anti-friction and anti-friction-wear-resistant polymer composite materials based on polyolefins], Kompozicionnie materiali, Volume 3, Pp:37-39, 2005.

[19] Gulyamov G., Negmatov N.S., Halimjanov T.S., Lutfullin K.L.; Kompozicionnie materiali i effektivnost ih primeneniya $\mathrm{v}$ kolkovih rabochih organah hlopkovih mashin i mehanizmov [Composite materials and the effectiveness of their use in peg working bodies of cotton machines and mechanisms], Kompozicionnie materiali, Volume 1, Pp: 54-58, 2001.

[20] Matrenin S.V., Ovechkin B.B.; Kompozicionnie materiali i pokritiya na polimernoy osnove [Composite materials and polymer-based coatings], TPU, 197p, 2008.

[21] Rogov V.A., Solov'ev V.V., Kopylov V.V.; Novie materiali $\mathrm{v}$ mashinostroeniy [New materials in mechanical engineering], RUDN, 324, 2008.

[22] Shevchenko V.G.; Osnovi fiziki polimernih kompozicionnih materialov [Fundamentals of Physics of Polymer Composite Materials], MGU imeni M. V. Lomonosova, 99p, 2010.

[23] Fetisov A.V., Agafonova G.V. Konstrukcionnie polimernie kompoziti [Structural polymer composites], VolgGTU, 104p, 2010.

[24] Ziyamukhamedova U.A., Bakirov L.Y., Rakhmatov E.A., Bektemirov B.Sh.; Structure and Properties of Heterocomposite Polymeric Materials and Coatings from them Obtained by Heliotechnological Method. International Journal of Recent Technology and Engineering (IJRTE), ISSN: 2277-3878, Volume-8, Issue-3S, Pp: 399402, 2019. 